\title{
Cost-effectiveness analysis of COVID-19 vaccination in Poland
}

\author{
Katarzyna Orlewska ${ }^{1}$, Waldemar Wierzba ${ }^{2,3}$, Andrzej Śliwczynski ${ }^{2,3}$
}

\author{
${ }^{1}$ Collegium Medicum, Jan Kochanowski University, Kielce, Poland \\ ${ }^{2}$ Satellite Campus in Warsaw, University of Humanities and Economics in Lodz, Poland \\ ${ }^{3}$ Central Clinical Hospital of the Ministry of the Interior and Administration, Warsaw, \\ Poland
}

Submitted: 28 July 2021, accepted: 7 December 2021

Online publication: 18 December 2021

Arch Med Sci 2022; 18 (4): 1021-1030

DOI: https://doi.org/10.5114/aoms/144626

Copyright $\odot 2022$ Termedia \& Banach

\section{Abstract}

Introduction: The aim of our study was to assess the potential value of the Comirnaty vaccine (BNT162b2) in Poland. A model was used to estimate patient events, direct medical costs, utilities, and cost-effectiveness for 1 year with and without implementation of the vaccine.

Material and methods: The Markov model with 1-week cycles was used to estimate patient events, direct medical costs, utilities, and cost-effectiveness for 1 year with and without implementing the Comirnaty vaccine in Poland. The incremental cost per quality-adjusted life-year (QALY) gained vs. no vaccine was calculated for the general population and selected agegroups. All costs are reported in PLN (average exchange rate in 2020: 1 EUR = 4.44 PLN).

Results: In the base case analysis the incremental cost per QALY gained associated with vaccinating the whole population is 6249 PLN. For individuals aged 60-69 years and $>80$ years vaccination is less costly and more effective than no vaccination. The incremental cost per QALY gained when vaccinating individuals aged $40-49$ and $30-39$ years is 28,135 PLN and 67,823 PLN, respectively. In the general population and in younger subpopulations the incremental cost-effectiveness ratio is most sensitive to the vaccine effectiveness, vaccine price, and SARS-CoV-2 infection rates.

Conclusions: When prioritization is required due to supply constraints, vaccination of the elderly is justified because it gives the highest number of QALY gained and generates savings for the health care system. Continual updates of the model concerning vaccine real-life effectiveness and epidemic course are required to refine the prioritisation scheme in the future.

Key words: cost-effectiveness, COVID-19, Poland, vaccine.

\section{Introduction}

The National Vaccination Program for the prevention of coronavirus disease 2019 (COVID-19) is one of the largest vaccination programs in Polish history. The first Polish citizen was vaccinated on $27^{\text {th }}$ December 2020 at the Central Clinical Hospital of the Ministry of Internal Affairs and Administration in Warsaw [1]. By the end of January 20211.2 million doses were administered, with a daily average of 53,476 [2]. All patients received the Pfizer BioNTech mRNA Comirnaty vaccine (BNT162b2), which was granted conditional marketing authorization by the European Commission on $21^{\text {st }}$ December 2020 [3]. Its approval was based on

\author{
Corresponding author: \\ Katarzyna Orlewska MD \\ Collegium Medicum \\ Jan Kochanowski \\ University \\ Kielce, Poland \\ Phone: +4822 2441606 \\ E-mail: korlewska@gmail. \\ com
}


the results of a large randomized clinical trial that evaluated the efficacy and safety in over 40,000 participants of the vaccination program [4]. The two-dose regimen of the Comirnaty vaccine $(30 \mu \mathrm{g} /$ dose administered 21 days apart) was found to be safe and 95\% (95\% Cl: 90.3-97.6\%) effective against COVID-19 in persons aged 16 years and older [4]. These results demonstrated that COVID-19 can be prevented by immunisation, and the vaccination programme may play an important role in reducing the substantial burden of the COVID-19 pandemic. The aim of this study was to assess the potential value of the Comirnaty vaccine in the Polish general population and in selected age groups. Given the constraints on vaccine availability, the results predicted by our cost-effectiveness analysis could be helpful in priority-setting decisions.

\section{Material and methods}

The study used a Markov model to estimate patient events, direct medical costs, utilities, and cost-effectiveness for 1 year with and without implementation of the Comirnaty vaccine. Figure 1 presents the structure of the model of SARS-CoV-2 infection and COVID-19 progression. Individuals enter the model as susceptible for SARS-CoV-2 infection. During each weekly cycle, individuals can move to the following states: "detected infection", "undetected infection", "non-infected", or "death", or they can remain in their current states as indicated by the arrows (Figure 1). A confirmed COVID-19 case ("detected infection") was defined as a positive result of real-time reverse transcriptase-polymerase chain reaction (RT-PCR) assay of nasal or pharyngeal swab specimens. An "undetected infection" was defined as a SARS-CoV-2 infection that had not been detected with a PCR test or a nasal or pharyngeal swab specimen. Patients in the "detected infection" state remained there for only 1 cycle, during which they entered a probability tree, which allocated patients through various levels of COVID-19 treatment (ambulatory care, hospitalization, hospitalisation + mechanical ventilation) to their ultimate resolution (recovered or dead). The authors assumed that no reinfection occurs within the 1-year period [5].

To compare the impact of age-based vaccination prioritization strategies, the incremental cost-effectiveness ratio (ICER) versus no vaccine was calculated for the "general population" and selected subpopulations: aged 30-39, 40-49, 60-69, and $>80$ years.

COVID-19-related transition probabilities were estimated based on Polish epidemiological data (Table I). In the base-case scenario for the general population, the weekly infection rate was calculated using data on the number of new cases in the first week of January 2021. For each age group the weekly infection rate was calculated based on data on the proportion of a given age group in the total number of cases and the size of a specific subpopulation.

The case-fatality ratio (CFR) for the general population was calculated for cases from the first week of January 2021, assuming a 14-day time lag between case diagnosis and death occurrence $[6,7]$. For each age group an age-specific CFR was applied based on data from the EWP register, November 2, 2020. In the base-case scenario a constant incidence rate and CFR were assumed over time. All-cause mortality was applied based on Polish life-expectancy tables for the total

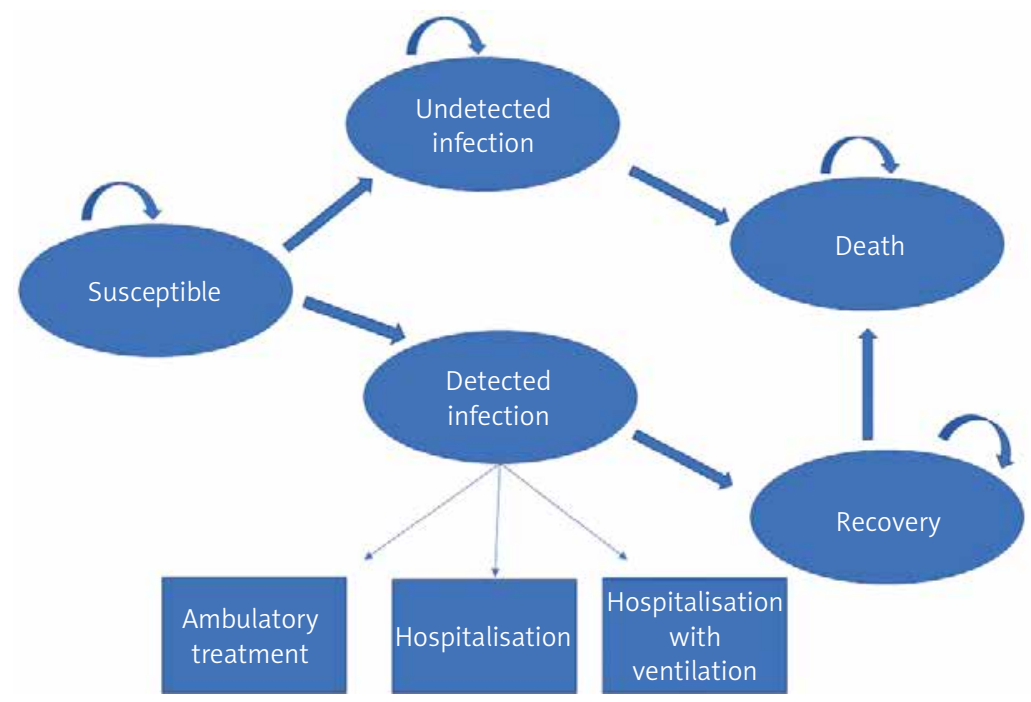

Figure 1. Model of SARS-CoV-2 infection and COVID-19 progression. Arrows show the transition between health states. Death from "detected infection" is due to COVID-19; death from other health states is due to other causes 
Table I. Parameters and base-case values used in the model

\begin{tabular}{|c|c|c|}
\hline Parameter & Base-case values & Source \\
\hline \multicolumn{3}{|l|}{ Epidemiological parameters } \\
\hline $\begin{array}{l}\text { Weekly attack rate: } \\
\text { General population } \\
\text { Population aged }>80 \\
\text { Population aged } 60-69 \\
\text { Population aged } 40-49 \\
\text { Population aged } 30-39\end{array}$ & $\begin{array}{l}0.00166 \\
0.00167 \\
0.00145 \\
0.00244 \\
0.00207\end{array}$ & $\begin{array}{l}\text { Calculated using data on the number of new } \\
\text { cases in the first week of January } 2021 \\
\text { Calculated based on data on the proportion of } \\
\text { a given age-group in the total number of cases } \\
\text { and the size of specific subpopulation }\end{array}$ \\
\hline $\begin{array}{l}\text { Case-fatality rate } \\
\text { General population } \\
\text { Population aged }>80 \\
\text { Population aged } 60-69 \\
\text { Population aged } 40-49 \\
\text { Population aged } 30-39\end{array}$ & $\begin{array}{l}3 \% \\
16.31 \% \\
2.62 \% \\
0.19 \% \\
0.08 \%\end{array}$ & $\begin{array}{c}\text { Calculated for cases from the first week of } \\
\text { January } 2021 \text { assuming a 14-day time lag } \\
\text { between case and death occurrence } \\
\text { Age-specific CFR: EWP register, November 2, } \\
2020\end{array}$ \\
\hline $\begin{array}{l}\text { Non-COVID } 19 \text { mortality rates } \\
\text { General population } \\
\text { Population aged }>80 \\
\text { Population aged } 60-69 \\
\text { Population aged } 40-49 \\
\text { Population aged } 30-39\end{array}$ & $\begin{array}{l}0.000205 \\
0.001993 \\
0.000314 \\
0.000048 \\
0.000023\end{array}$ & {$[7]$} \\
\hline $\begin{array}{l}\text { Undetected infections: detected } \\
\text { infections ratio }\end{array}$ & 1.08 & {$[8]$} \\
\hline \multicolumn{3}{|l|}{ Vaccine efficacy } \\
\hline $\begin{array}{l}\text { 1. dose } \\
\text { 2. dose }\end{array}$ & $\begin{array}{l}52 \% \\
95 \%\end{array}$ & {$[4]$} \\
\hline \multicolumn{3}{|l|}{ Treatment } \\
\hline $\begin{array}{l}\text { Proportion of patients treated } \\
\text { in hospital among all detected } \\
\text { cases } \\
\text { General population } \\
\text { Population aged }>80 \\
\text { Population aged } 60-69 \\
\text { Population aged } 40-49 \\
\text { Population aged } 30-39\end{array}$ & $\begin{array}{c}6 \% \\
51 \% \\
19 \% \\
3 \% \\
2.2 \%\end{array}$ & $\begin{array}{c}\text { Calculated from Polish data January } 2021^{*} \\
\text { Calculated based on data on the proportion } \\
\text { of a given age-group in the total number of } \\
\text { hospitalised cases [15] }\end{array}$ \\
\hline \multicolumn{3}{|l|}{$\begin{array}{l}\text { Proportion of patients admitted } \\
\text { to an intensive care unit (ICU) } \\
\text { and being placed on a ventilator } \\
\text { among hospitalised patients } \\
\text { General population }\end{array}$} \\
\hline \multicolumn{3}{|l|}{ Event duration } \\
\hline $\begin{array}{l}\text { COVID-19 symptoms among all } \\
\text { confirmed infections }\end{array}$ & 14 days & [14] \\
\hline $\begin{array}{l}\text { Hospitalization among detected } \\
\text { infections not requiring ICU or } \\
\text { ventilator }\end{array}$ & 11.54 days & {$[16]$} \\
\hline $\begin{array}{l}\text { Hospitalization among detected } \\
\text { infections with ventilator as } \\
\text { highest level of care }\end{array}$ & 14.56 days & {$[16]$} \\
\hline $\begin{array}{l}\text { Duration of symptoms before } \\
\text { hospitalisation }\end{array}$ & 4 days & {$[15]$} \\
\hline \multicolumn{3}{|l|}{ Health state utility parameters } \\
\hline $\begin{array}{l}\text { Detected infection symptoms } \\
\text { disutility weight }\end{array}$ & 0.19 & {$[13]$} \\
\hline
\end{tabular}


Table I. Cont.

\begin{tabular}{|c|c|c|}
\hline Parameter & Base-case values & Source \\
\hline $\begin{array}{l}\text { Detected infection } \\
\text { hospitalization as highest } \\
\text { setting disutility weight }\end{array}$ & 0.3 & {$[13]$} \\
\hline $\begin{array}{l}\text { Detected infection } \\
\text { hospitalization with ventilator } \\
\text { as highest level of care }\end{array}$ & 0.6 & [13] \\
\hline \multicolumn{3}{|l|}{ Costs } \\
\hline Vaccine (per dose) & 38.05 PLN & [19] \\
\hline Vaccine administration (per dose) & 61.24 PLN & {$[18]$} \\
\hline $\begin{array}{l}\text { COVID-19 treatment: ambulatory } \\
\text { care only (per event) }\end{array}$ & 370 PLN & $\begin{array}{c}2 \text { physicians visits (140 PLN/consultation) + } \\
\text { test (90 PLN) }\end{array}$ \\
\hline $\begin{array}{l}\text { COVID-19 treatment: } \\
\text { hospitalisation without } \\
\text { ventilator (per day) }\end{array}$ & 1026 PLN & {$[22]$} \\
\hline $\begin{array}{l}\text { COVID-19 treatment: } \\
\text { hospitalisation with ventilator } \\
\text { (per day) }\end{array}$ & 4321 PLN & {$[22]$} \\
\hline
\end{tabular}

population in the case of the general population, or age-specific populations in the cases of subpopulations aged 30-39, 40-49, 60-69, and $>80$ years [8]. Based on epidemiological data and mathematical models, the ratio of undetected to detected infections was assumed to be 1.08 [9]. The proportion of infected people requiring hospitalisation or admitted to the intensive care unit (ICU) and being placed on a ventilator were calculated from the data reported by Polish Ministry of Health in January 2021 and from [10]. The expected number of life years lost due to deaths from COVID-19 were calculated using expected survival by age as predicted by Statistics Poland in 2019 [7]. Age-specific utility values for individuals without detected infection, obtained using the 3-level EQ-5D (EQ-5D-3L) questionnaire in a large, representative sample of the Polish population [11], were used to calculate the present value of the quality-adjusted life-years (QALYs) lost due to COVID-19 death, assuming a 55:45 male-to-female ratio [12] and applying a 3.5\% discount rate [13]. A QALY decrement attributable to the time spent with COVID-19 symptoms was applied to anyone experiencing a detected infection. Disutility weights were obtained from a recent report on pricing models for COVID-19 treatments published by the Institute for Clinical and Economic Review, in which the disutility weights were derived from data collected in patients experiencing influenza and Clostridium difficile infection [14]. In our analysis these weights were applied for each day that a patient experienced symptoms and was hospitalised for COVID-19, dependent on their level of care. COVID-19 symptoms were assumed to persist for 14 days in all non-hospital- ized patients, representing the median time from onset to clinical recovery for mild cases reported by the World Health Organization (WHO)-China Joint Mission on COVID-19 [15]. The duration of symptoms before hospitalisation was assumed to be 4 days [16]. For individuals hospitalized for COVID-19, a length of stay (LOS) of 11.54 (95\% Cl: 11.4-11.7) days was assumed, representing the mean LOS among non-severe patient categories hospitalized with COVID-19 reported in a meta-analysis of results from 9 studies [17]. Longer estimates of 14.56 (95\% Cl: 14.23-14.90) days were assumed for patients treated in the ICU with ventilation, reflecting the mean LOS among severe patient categories reported in a meta-analysis of results from 11 studies [17]. Although there is evidence of long-term COVID-19 health consequences [18], we did not include these in the model to be conservative.

Vaccine efficacy was modelled as reducing the probability of transitioning from the "susceptible" state to the "detected infection" state. Single-dose efficacy was 52\%, and 2-dose efficacy was 95\% [4]. In the base-case scenario the vaccine efficacy was assumed to remain at the same level for the 1-year time horizon of the analysis.

A Polish public health care payer perspective was used, and all costs are reported in 2020 PLN (average exchange rate in 2020: 1 EUR $=4.44$ PLN). In the base-case analysis unit costs calculated by the Polish Agency for Health Technology Assessment and Tariff System (AOTMiT) were applied $[19,20]$. The vaccine cost was estimated as reported by the Ministry of Health in 2020 [21].

A series of deterministic sensitivity analyses were conducted to investigate the impact of alter- 
native inputs and assumptions, including alternative sets of infection rates $( \pm 50 \%$ of the base case values), alternative CFR ( $\pm 50 \%$ of the base case values), vaccine efficacy ( $0 \%$ after first dose and $50 \%$ after second dose), proportion of patients treated in hospital ( $\pm 50 \%$ of the base case values), treatment costs (330 PLN per day in hospital, 1154 PLN per day under ventilation), duration of hospitalisation (13.79 and 15.96 days), vaccination cost (80 PLN per dose of vaccine; 95.70 PLN per administration), and age-specific utility values for individuals without detected infection obtained using EQ-VAS [11]. We provide also a real-life scenario in which the effectiveness of the vaccine decreased with time after vaccination, according to data provided by a retrospective cohort study evaluating the effectiveness of Comirnaty among members of a large integrated health-care system in the USA until 6 months after full vaccination [22]. In this scenario effectiveness against infection declined from $88 \%$ during the first month after full vaccination to $47 \%$ after 5 months in the general population, from $89 \%$ to $39 \%$ for those aged $30-39$ years, from $87 \%$ to $50 \%$ for those aged $40-49$ years, and from $80 \%$ to $43 \%$ for those aged 60 years and older [22].

\section{Results}

The number of detected infections, deaths, and costs per 1000 individuals expected in 1 year for scenarios without the vaccine and with a vaccine in different populations are presented in Table II. The number of detected infections prevented by vaccination per 1000 individuals depends on the SARS-CoV-2 attack rate in a given population, and under base case assumptions this amounts to
72.5 in the general population, 88.75 in individuals aged 30-39 years, 102.57 in individuals aged 40-49 years, 63.64 in individuals aged 60-69 years, and 69.16 in individuals aged $>80$ years. The number of deaths prevented by vaccination per 1000 individuals in the general population is 2.1, and it varied from 0.07 in the subpopulation aged 30-39 years to 10.9 in the subpopulation aged $>80$ years, depending on the CFR in individual age groups. Scenario analysis showed that both the number of detected infections and the number of deaths prevented by vaccination decreases as the attack rate or vaccine efficacy decreases.

The costs in the scenario without vaccination increase as the risk of hospitalization increases, and in the subpopulation aged $>80$ years they are approximately 10 times higher than in the subpopulation aged 30-39 years. In the scenario with vaccination, the main cost driver in all analysed groups is the cost of vaccine and vaccine administration. By lowering the number of detected infections, vaccines reduce the treatment cost. In the younger age groups with lower risk of hospitalisation and, in consequence lower mean cost per patient treated (727 PLN and 872 PLN in individuals aged 30-39 and 40-49 years, respectively; Table III), reduction of treatment costs due to vaccination is too small to compensate expenses linked to vaccination. In contrast, in older subpopulations with higher risk of hospitalisation and, in consequence higher mean cost per patient treated (3537 PLN in individuals aged 60-69 years, 13,632 PLN in individuals aged > 80 years; Table III), vaccination generates savings in comparison to no vaccination.

Table II. Number of detected infections, deaths, and costs per 1000 individuals expected in 1 year for scenarios without the vaccine and with a vaccine in different populations under base-case and extreme scenario assumptions

\begin{tabular}{|c|c|c|c|c|c|c|}
\hline \multirow[t]{2}{*}{ Population } & \multicolumn{2}{|c|}{$\begin{array}{c}\text { Cost per } 1000 \text { individuals (PLN) } \\
\text { base-case } \\
\text { (worst; best scenario) }\end{array}$} & \multicolumn{2}{|c|}{$\begin{array}{l}\text { Number of expected deaths per } \\
1000 \text { individuals base-case } \\
\text { (worst; best scenario) }\end{array}$} & \multicolumn{2}{|c|}{$\begin{array}{l}\text { Number of detected infections } \\
\text { per } 1000 \text { individuals base-case } \\
\text { (worst; best scenario) }\end{array}$} \\
\hline & No vaccine & Vaccine & No vaccine & Vaccine & No vaccine & Vaccine \\
\hline $\begin{array}{l}\text { General } \\
\text { population }\end{array}$ & $\begin{array}{l}104,652.83 \\
(20,490.69 \\
231,806,60)\end{array}$ & $\begin{array}{l}206,889.36 \\
(362,376.02 \\
217,574.22)\end{array}$ & $\begin{array}{c}2.28 \\
(0.59 ; 4.92)\end{array}$ & $\begin{array}{c}0.18 \\
(0.32 ; 0.4)\end{array}$ & $\begin{array}{c}78.74 \\
(41.14 ; 113.04)\end{array}$ & $\begin{array}{c}6.23 \\
(22 ; 9.19)\end{array}$ \\
\hline $\begin{array}{l}\text { Population } \\
\text { aged 30-39 }\end{array}$ & $\begin{array}{c}68,349.94 \\
(20,889.47 \\
134,676.01)\end{array}$ & $\begin{array}{l}204,047.87 \\
(362,614.66 \\
209,779.10)\end{array}$ & $\begin{array}{c}0.0745 \\
(0.02 ; 0.16)\end{array}$ & $\begin{array}{c}0.006 \\
(0.01 ; 0.013)\end{array}$ & $\begin{array}{c}96.46 \\
(50.88 ; 137.28)\end{array}$ & $\begin{array}{c}7.71 \\
(27.28 ; 11.33)\end{array}$ \\
\hline $\begin{array}{l}\text { Population } \\
\text { aged } 40-49\end{array}$ & $\begin{array}{c}94,886.64 \\
(25,497.64 \\
190,051.71)\end{array}$ & $\begin{array}{l}206,315.64 \\
(365,121.68 \\
214,655.69)\end{array}$ & $\begin{array}{c}0.2 \\
(0,054 ; 0.43)\end{array}$ & $\begin{array}{l}0.017 \\
(0.029 \\
0.037)\end{array}$ & $\begin{array}{l}111.6 \\
(59.4 ; \\
157.4)\end{array}$ & $\begin{array}{c}9.03 \\
(31.94 ; 13.22)\end{array}$ \\
\hline $\begin{array}{l}\text { Population } \\
\text { aged 60-69 }\end{array}$ & $\begin{array}{l}237,785.04 \\
(28,693.99 \\
572,192.99)\end{array}$ & $\begin{array}{l}217,435.59 \\
(366,750.40 \\
245,016.28)\end{array}$ & $\begin{array}{c}1.75 \\
(0.45 ; 3.79)\end{array}$ & $\begin{array}{c}0.139 \\
(0.24 ; 0.31)\end{array}$ & $\begin{array}{c}69.07 \\
(38.88 ; 99.72)\end{array}$ & $\begin{array}{c}5.43 \\
(19.17 ; 8.03)\end{array}$ \\
\hline $\begin{array}{l}\text { Population } \\
\text { aged > } 80\end{array}$ & $\begin{array}{c}1,000,022 \\
(79,067.4 \\
2,398,180.7)\end{array}$ & $\begin{array}{c}279,855.02 \\
(393,878.06 \\
399,932.74)\end{array}$ & $\begin{array}{c}11.86 \\
(3.1 ; 25.45)\end{array}$ & $\begin{array}{c}0.967 \\
(1.67 ; 2.14)\end{array}$ & $\begin{array}{c}75.23 \\
(39.44 ; 107.39)\end{array}$ & $\begin{array}{c}6.07 \\
(21.16 ; 8.95)\end{array}$ \\
\hline
\end{tabular}


Table III. Mean weighted cost per patient treated due to COVID-19, mean weighted loss of QALY due to COVID-19 treatment, and QALY lost per death due to COVID-19 under base-case and extreme scenario assumptions. For the worst scenario the following assumptions were made: single-dose efficacy $0 \%$ and 2-dose efficacy $50 \%$; SARSCoV-2 attack rates, CFR and proportion of hospitalised patients $50 \%$ of base-case values, price of vaccine 80 PLN/ dose, treatment costs (330 PLN per day in hospital, 1154 PLN/day with ventilation), vaccination cost (80 PLN per dose of vaccine; 95.70 PLN per administration), age-specific utility values for individuals without detected infection, obtained using EQ-VAS. For the best scenario, the following assumptions were made: SARS-Cov-2 attack rates, CFR and proportion of hospitalised patients was assumed to be $150 \%$ of base-case values, duration of stay in hospital and in hospital with ventilation 13.79 and 15.96 days, respectively

\begin{tabular}{|lccc|}
\hline Population & $\begin{array}{c}\text { Cost/patient treated } \\
\text { base-case } \\
\text { (worst; best scenario) }\end{array}$ & $\begin{array}{c}\text { QALY lost/patient treated } \\
\text { base-case } \\
\text { (worst; best scenario) }\end{array}$ & $\begin{array}{c}\text { QALY lost/death } \\
\text { base-case } \\
\text { (worst; best scenario) }\end{array}$ \\
\hline General population & $1,370.876$ & 0.00763 & 7.54 \\
& $(512.13 ; 2103.40)$ & $(0.00746 ; 0.00797)$ & $(5.66 ; 7.54)$ \\
\hline Population aged 30-39 & 727.3 & 0.00741 & 19.87 \\
& $(422,1 ; 1005.58)$ & $(0.00735 ; 0.00754)$ & $(16.25 ; 19.87)$ \\
\hline Population aged 40-49 & 872.35 & 0,00746 & 17.09 \\
& $(441,06 ; 1236.7)$ & $(0.00737 ; 0.00763)$ & $(13.56 ; 17.09)$ \\
\hline Population aged 60-69 & $3,536.628$ & 0.00838 & 10.43 \\
& $(822.44 ; 5887.99)$ & $(0.00783 ; 0.00947)$ & $(7.91 ; 10.43)$ \\
\hline Population aged > 80 & $13,632.02$ & 0.01157 & 2.12 \\
& $(2058.89 ; 22,870.32)$ & $(0.00943 ; 0.01525)$ & $(1.55 ; 2.12)$ \\
\hline
\end{tabular}

QALY gain in all analysed populations is primarily driven by preventing deaths (Figure 2). Reduction of disutility experienced by patients due to the morbidity associated with COVID-19 has only a minimal effect on the amount of total QALY. Because the risk of COVID-19 death increases with age, QALY gain (total and assigned to deaths) is highest in older populations, although 1 death

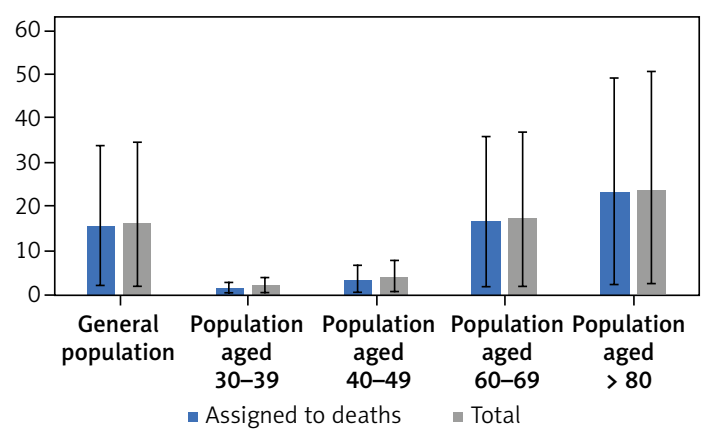

Figure 2. QALY gained per 1000 individuals versus no vaccination: total and assigned to deaths. Values obtained in base case, worst and best scenarios. For the worst scenario the following assumptions were made: single-dose efficacy $0 \%$ and 2-dose efficacy 50\%; SARS-CoV-2 attack rates, CFR and proportion of hospitalised patients $50 \%$ of base case values, price of vaccine 80 PLN/dose, treatment costs (330 PLN per day in hospital, 1154 PLN/day with ventilation), vaccination cost (80 PLN per dose of vaccine; 95.70 PLN per administration), age-specific utility values for individuals without detected infection, obtained using EQ-VAS. For the best scenario the following assumptions were made: SARS-Cov-2 attack rates, CFR and proportion of hospitalised patients was assumed to be $150 \%$ of base case values, duration of stay in hospital and in hospital with ventilation 13.79 and 15.96 days, respectively in individuals aged $>80$ years leads to a loss of 2.12 QALY, while 1 death among individuals aged 30-39 years leads to a loss of 19.9 QALY (Table III).

Results of incremental analyses are presented in Table IV. In the base-case analysis, the incremental cost per QALY gained associated with vaccinating the Polish general population is 6249 PLN. For individuals aged 60-69 and > 80 years vaccination is less costly and more effective than no vaccination. The incremental cost per QALY gained when vaccinating individuals aged 40-49 and $30-39$ years is 28,135 PLN and 67,823 PLN, respectively. In the general population and in younger subpopulations ICER is most sensitive to the vaccine effectiveness, vaccine price, and SARS-CoV- 2 attack rates. When vaccine efficacy is assumed to be $0 \%$ after the first dose and $50 \%$ after the second dose, or when SARS-CoV-2 attack rates are assumed to decrease by $50 \%$, the ICER for the subpopulation aged 30-39 years is above the standard willingness-to-pay-threshold, which in Poland is $3 \times \mathrm{GDP} /$ per capita $(147,024$ PLN/QALY gained in 2020). In the real-world scenario, in which the effectiveness of the vaccine decreased with time, vaccination remained cost saving in the subpopulation aged $>80$ years, and cost effective in the general population and subpopulations aged 30-39, 40-49, and 60-69 years.

Varying the probability of hospitalisation or cost of hospitalisations has more impact on the ICER in the subpopulation aged 60-69 years than in the younger groups. Under the worst scenario assumptions vaccination becomes non cost-effective in all analysed populations except individuals aged $>80$ years. Under base-case assumptions a vaccine targeted to the general population 
Table IV. Results of incremental analysis

\begin{tabular}{|c|c|c|c|c|c|}
\hline \multirow[t]{2}{*}{ Scenario } & \multicolumn{5}{|c|}{ Incremental cost per QALY gained [PLN] } \\
\hline & $\begin{array}{l}\text { General } \\
\text { population }\end{array}$ & $\begin{array}{l}\text { Population } \\
\text { aged } 30-39\end{array}$ & $\begin{array}{l}\text { Population } \\
\text { aged } 40-49\end{array}$ & $\begin{array}{l}\text { Population } \\
\text { aged } 60-69\end{array}$ & $\begin{array}{l}\text { Population } \\
\text { aged }>80\end{array}$ \\
\hline Base-case & 6249 & 67,823 & 28,135 & Cost saving & Cost saving \\
\hline \multicolumn{6}{|l|}{ Attack rate: } \\
\hline$+50 \%$ & 2,571 & 38,076 & 13,718 & Cost saving & Cost saving \\
\hline$-50 \%$ & 17,337 & 156,210 & 72,191 & 9445 & Cost saving \\
\hline \multicolumn{6}{|l|}{ Case-fatality rate: } \\
\hline$+50 \%$ & 4,220 & 50,374 & 20,103 & Cost saving & Cost saving \\
\hline$-50 \%$ & 12,093 & 102,270 & 47,565 & Cost saving & Cost saving \\
\hline \multicolumn{6}{|l|}{ Proportion of patients treated in hospital: } \\
\hline$+50 \%$ & 4104 & 59,468 & 21,940 & Cost-saving & Cost saving \\
\hline$-50 \%$ & 8404 & 75,576 & 34,607 & 4505 & Cost saving \\
\hline $\begin{array}{l}\text { Vaccine efficacy ( } 0 \% \text { after first dose and } \\
50 \% \text { after second dose) }\end{array}$ & 18,481 & 168,598 & 79,535 & 10,340 & Cost saving \\
\hline $\begin{array}{l}\text { Vaccine efficacy declines with time (real- } \\
\text { word scenario) }^{1}\end{array}$ & 13,036 & 135,337 & 54,423 & 6976 & Cost-saving \\
\hline $\begin{array}{l}\text { Treatment costs ( } 330 \text { PLN per day in } \\
\text { hospital, } 1154 \text { PLN/day with ventilation) }\end{array}$ & 9316 & 78,823 & 37,172 & 6927 & Cost saving \\
\hline $\begin{array}{l}\text { Event duration (hospitalisation } 13.79 \\
\text { days; hospitalisation with ventilation } \\
\text { 15.96) }\end{array}$ & 5552.07 & 65,191 & 26,044 & Cost saving & Cost saving \\
\hline $\begin{array}{l}\text { Age-specific utility values for individuals } \\
\text { without detected infection, obtained } \\
\text { using EQ-VAS }\end{array}$ & 8248.07 & $77,419.56$ & $33,802.50$ & Cost saving & Cost saving \\
\hline $\begin{array}{l}\text { Vaccination cost ( } 80 \text { PLN per dose of } \\
\text { vaccine; } 95.70 \text { PLN per administration) }\end{array}$ & 15,592 & 144,181 & 66,714 & 7668 & Cost saving \\
\hline Worst scenario² & 201,178 & $1,081,363$ & 631,849 & 188,674 & 131,329 \\
\hline Best scenario 3 & Cost-saving & 19,613 & 3,127 & Cost-saving & Cost-saving \\
\hline
\end{tabular}

${ }^{1}$ In the real-word scenario the effectiveness of the vaccine in fully vaccinated individuals decreased with time after vaccination: from $88 \%$ during the first month after full vaccination to $47 \%$ after 5 months for the general population, from $89 \%$ to $39 \%$ for those aged $30-$ 39 years, from $87 \%$ to $50 \%$ for those aged $40-49$ years, and from $80 \%$ to $43 \%$ for those aged 60 years and older [19]. ${ }^{2}$ For the worst scenario, the following assumptions were made: single-dose efficacy 0\% and 2-dose efficacy 50\%; SARS-CoV-2 attack rates, CFR and proportion of hospitalised patients $50 \%$ of base case values, price of vaccine 80 PLN/dose, treatment costs (330 PLN per day in hospital, 1154 PLN/day with ventilation), vaccination cost (80 PLN per dose of vaccine; 95.70 PLN per administration), age-specific utility values for individuals without detected infection, obtained using EQ-VAS. ${ }^{3}$ For the best scenario, the following assumptions were made: SARS-Cov-2 attack rates, CFR and proportion of hospitalised patients was assumed to be $150 \%$ of base-case values, duration of stay in hospital and in hospital with ventilation 13.79 and 15.96 days, respectively.

would have to be priced at over 1200 PLN per dose to exceed the ICER threshold of 147,025 PLN/QALY. Under the worst scenario assumptions the vaccine would have to be priced at 35 PLN per dose to exceed an ICER threshold value when targeted to the general population.

\section{Discussion}

Results of the cost-effectiveness analysis show that the Comirnaty vaccine is good value for money, even though the model considers benefits related to reducing the probability of a symptomatic SARS-CoV-2 infection and only direct health care system costs. The value of vaccination is primarily driven by the risk of hospitalisation and risk of death in different age groups. Vaccination ap- peared to be cost saving in subpopulations with high risk of hospitalisation and high incidence of ventilation. ICER increases as the risk of hospitalisation and the risk of death decrease. Our model shows that in adults aged 30-49 years more infections can be prevented due to vaccination, but mortality and QALY loss are minimised more when the vaccine is targeted to adults over 60 years old. This evidence indicates that the best option for preventing morbidity and mortality in the initial phase of the vaccination programme is to directly protect persons most at risk. In the situation of limited supply of vaccine, a simple age-based strategy meets both ethical (providing direct protection to persons most at risk of morbidity and mortality) and economic criteria (where we can achieve the most health benefit for the money 
spent). Wider use of COVID-19 vaccines will provide a better understanding of whether they can not only prevent infection, but also onward transmission in the population. Data on vaccine impact on transmission will potentially change the advantage of vaccinating younger individuals, if vaccination is proven to prevent community spread. Recent evidence indicates that individuals aged 20-49 years are the only age group sustaining resurgent SARS-CoV-2 transmission, with reproduction numbers well above one, and that at least 65 of 100 COVID-19 infections originate from individuals aged 20-49 years [23]. Targeting transmission-blocking vaccines to adults aged 20-49 years might be an important consideration in halting resurgent epidemics and preventing COVID-19-attributable deaths.

The strength of this study is that the model reflects the course of SARS-CoV-2 infection in the Polish population, and given the constraints on vaccine availability, it might be helpful in rationalizing priority-setting decisions in the Polish setting. The key parameters influencing the value of vaccination, such as SARS-CoV-2 attack rates, mortality, risk of hospitalisation, and vaccine effectiveness, were estimated based on data available in January 2021, i.e. when the vaccination programme started in Poland. A recently published study showed that the efficacy of Comirnaty peaked at $96.2 \%$ during the interval from 7 days to less than 2 months after the second dose and declined gradually to $83.7 \%$ from 4 months after the second dose to the data cut-off date - an average decline of approximately $6 \%$ every 2 months [24]. Series of deterministic sensitivity analysis showed that vaccination remained cost-effective over a wide range of parameters, including vaccine efficacy ( $0 \%$ after first dose and $50 \%$ after second dose). However, it should be noted that longer-term estimates are highly uncertain due to possible changes in policy, individual behaviour, SARS-CoV-2 virulence, and updated evidence on vaccine effectiveness in a real-life setting. The model should therefore be continually refined based on the availability of new data.

Our model quantifies the potential impact of the vaccine on cumulative incidence, mortality, and QALY lost. Consistent with available evidence, the vaccine's ability to block transmission was not included. Future data on the impact of the vaccine on the spread of infection would undoubtedly allow more comprehensive assessment of the value of vaccination, mainly in the younger population.

Certain limitations of the study should be mentioned. The variation in both disease susceptibility and disease severity was addressed by age only, while other factors may play a role, e.g. viral mutation, occupations predisposing to frequent contact with SARS-CoV-2-infected persons, comorbidity, or access to health care. However, current evidence strongly indicates that the single greatest risk of mortality from COVID-19 is age [25]. Because the prevalence of comorbidity increases with age, an age-based prioritisation strategy is also likely to increase vaccine uptake in those with clinical risk factors. Vaccinating adolescents is anticipated to contribute to a reduction in SARS-CoV-2 transmission in the broader population. However, based on available data, this remains difficult to assess. There is currently some uncertainty regarding the relative contribution by adolescents to the transmission of SARS-CoV-2 in the wider community. Once a large proportion of adults are vaccinated, susceptible children and adolescents will account for a higher proportion of continued infections in the community contributing to transmission. Further studies conducted after detection of the SARS-CoV-2 variants with higher transmissibility will be needed to assess benefits from vaccination in children and adolescents. Moreover, the model should be continually refined based on the availability of new data, e.g. booster recommendations.

Furthermore, although health-care workers were the first vaccinated group in Poland, our model did not assess the value of vaccination of priority. This value would be underestimated without including other factors that cannot be reflected in ICER but should be considered in vaccine prioritization, which contributes to the health and well-being of the community [26].

Our analysis does not include costs of productivity loss and other societal costs associated with restrictions aimed at limiting the spread of the virus. Because the younger population is most impacted by them, considering societal costs in the analysis would augment the cost-effectiveness of the vaccination programme in this age group. We have conservatively not included other costs that might potentially be reduced by vaccination: costs associated with diagnostic testing, costs indirectly associated with COVID-19 (such as cost of depression or cost linked to exacerbation of diseases due to pandemic-related delay in treatment), and costs of long-term COVID-19 complications. Taking these costs into account would make vaccination even more cost effective in comparison to no vaccination.

Public health and economic impacts of a hypothetical vaccine for SARS-CoV-2 were assessed in 3 published studies, all performed before the start of the vaccine programmes $[13,27,28]$. The epidemiological models used in these studies were calibrated to the observations in spring 2020, while our model was based on data available in January 2021. In terms of the time horizon (1-year), modelling technique (Markov model), and out- 
come measure (QALY gained), US studies [14, 28] were similar to our analysis. A Danish study [27] used a differential equation model and a time horizon of 6 months, and reported outcome with gained life years. According to country-specific requirements, the results were discounted at a $3 \%$ discount rate in US studies, and $2 \%$ and $4 \%$ in the Danish study. Assumptions regarding vaccine efficacy and costs were also different: efficacy $90 \% / 100$ USD per course [28], 2-dose efficacy of $60 \%$ and single-dose efficacy of $40 \%$ and $25 \%$ of 2-dose efficacy for those aged 18-54 years and $>55 / 70$ USD per course [14], efficacy 100\%/300 to 500 DKK per course [27]. One US study included costs of the productivity loss [28], and the Danish study assumed that vaccination would reduce testing costs [27].

Similarly to our cost-effectiveness analysis, all the above-mentioned studies found vaccination to be good value for money in comparison to no vaccination. Padula et al. reported that in the entire US population, treatment and vaccination were more efficient than social distancing alone, although a vaccination program would provide greater QALY gains and reduce costs more significantly than a treatment option based on currently available data about COVID-19 outcomes [28]. Kohli et al. divided the population into groups based on age; risk and age; and occupation and age, and they reported that vaccination would be cost saving in the population at highest risk of complications from COVID-19 (among those aged $>65$ years), and in other risk groups the ICERs would be well under standard willingness-to-pay thresholds cited in the US, which range from $\$ 50,000$ to $\$ 150,000$ per QALY gained [14].

Debrabant et al. demonstrated that vaccination of the population aged $>60$ years in most cases is more cost effective than a vaccination strategy targeted only at the population aged $>60$ years. Furthermore, the results show that an extension of the target group from the elderly population only to also include younger populations comes with an increasing cost per life year gained [27].

In conclusion, COVID-19 vaccination turns out to be a highly cost-effective intervention in the Polish setting. Our study indicates that given the current epidemiological situation in Poland, the best option for preventing morbidity and mortality in the initial phase of the vaccination programme is to directly protect the population with highest risk of morbidity and mortality. When prioritization is required due to supply constraints, vaccination of the elderly is justified because it allows the highest number of QALY gained and generates savings for the health care system. Continually updating the model based on new information concerning real-life vaccine effectiveness and the epidemic course is required to refine the prioritisation scheme in the future.

\section{Conflict of interest}

The authors declare no conflict of interest.

\section{References}

1. Szarowska A, Zaczyński A, Szymański P, et al. Initiation of the COVID-19 vaccination program in Poland: vaccination of the patient "zero" and first experience from the Central Clinical Hospital of the Ministry of Internal Affairs and Administration. Pol Arch Intern Med 2021; 131: 101-2.

2. COVID-19 vaccination report. https://www.gov.pl/web/ szczepimysie/raport-szczepien-przeciwko-covid-19. Accessed 10 February, 2021.

3. Comirnaty European Public Assessment Report (EPAR). https://www.ema.europa.eu/en/medicines/human/ EPAR/comirnaty. Accessed January 27, 2021.

4. Polack FP, Thomas SJ, Kitchin N, et al. Safety and efficacy of the BNT162b2 mRNA Covid-19 vaccine. N Engl J Med 2020; 383: 2603-15.

5. Graham MS, Sudre CH, May A, et al. Changes in symptomatology, reinfection, and transmissibility associated with the SARS-CoV-2 variant B.1.1.7: an ecological study. Lancet Public Health 2021; 6: e335-45.

6. Linton NM, Kobayashi T, Yang Y, et al. Incubation period and other epidemiological characteristics of 2019 novel coronavirus infections with right truncation: a statistical analysis of publicly available case data. J Clin Med 2020; 9: 538

7. Wilson N, Kvalsvig A, Barnard LT, Baker MG. Case-fatality risk estimates for COVID-19 calculated by using a lag time for fatality. Emerg Infect Dis 2020; 26: 1339-441.

8. Life expectancy in Poland. https://stat.gov.pl/en/topics/population/life-expectancy/life-expectancy-in-poland,1,3.html. Accessed January 28, 2021.

9. Melis M, Littera R. Undetected infectives in the Covid-19 pandemic. Int J Infect Dis 2021; 104: 262-8.

10. Neumann-Podczaska A, Chojnicki M, Karbowski LM, et al. Clinical characteristics and survival analysis in a small sample of older COVID-19 patients with defined 60-day outcome. Int J Environ Res Public Health 2020; 17: 8362.

11. Golicki D, Niewada M. General population reference values for 3-level EQ-5D (EQ-5D-3L) questionnaire in Poland. Pol Arch Intern Med 2015; 125: 18-26.

12. Peckham H, de Gruijter NM, Raine C, et al. Male sex identified by global COVID-19 meta-analysis as a risk factor for death and ITU admission. Nat Commun 2020; 11: 6317.

13. Guidelines for conducting health technology assessment (HTA) version 3.0 August $2016 \mathrm{https}: / /$ www.aotm. gov.pl/media/2020/07/20160913_Wytyczne_AOTMiT. pdf. Accessed January 27, 2021.

14. Kohli M, Maschio M, Becker D, Weinstein MC. The potential public health and economic value of a hypothetical COVID-19 vaccine in the United States: use of cost-effectiveness modeling to inform vaccination prioritization. Vaccine 2021; 39: 1157-64.

15. Report of the World Health Organization (WHO)-China Joint Mission on COVID-19. https://www.who.int/docs/ default-source/coronaviruse/who-china-joint-missionon-covid-19-final-report.pdf. Accessed January 27, 2021. 
16. Berenguer J, Ryan P, Rodríguez-Baño J, et al. Characteristics and predictors of death among 4035 consecutively hospitalized patients with COVID-19 in Spain. Clin Microbiol Infect 2020; 26: 1525-36.

17. Sarmadi M, Kakhki S, Foroughi M, et al. Hospitalization period of COVID-19 for future plans in hospital. Br J Surg 2020; 107: e427-8.

18. Huang C, Huang L, Wang Y, et al. 6-month consequences of COVID-19 in patients discharged from hospital: a cohort study. Lancet 2020; 397: 220-32.

19. Analiza kosztów i wycena świadczenia polegającego na szczepieniu przeciw Sars-Cov-2 Opracowanie (Wersja 2) nr WT.541.13.2020 data ukończenia 3.12.2020 https:// bipold.aotm.gov.pl/assets/files/zlecenia_mz/2020/305/ RPT/2020.12.03 szczepienia_SARS-COV-2_opracowanie_wersja2_publ_BIP.pdf. Accessed January 17, 2021.

20. Finansowanie leczenia pacjentów z COVID-19 w szpitalachtradycyjnychitymczasowych.https://www.nfz.gov.pl/ aktualnosci/aktualnosci-centrali/finansowanie-leczenia-pacjentow-z-covid-19-w-szpitalach-tradycyjnych-itymczasowych,7849.html. Accessed January 17, 2021.

21. Ocena skutków regulacji (OSR) do projektu rozporzadzenia Ministra Zdrowia w sprawie metody zapobiegania COVID-19. http://biznes.pap.pl/pl/news/pap/ info/3031971,rzad-ma-zakontraktowane-do-60-522-mln-dawek-szczepionek-w-2021-roku---osr. Accessed January 17, 2021.

22. Tartof S, Slezak JM, Fischer $\mathrm{H}$, et al. Effectiveness of nRNA BNT162b2 COVID-19 vaccine up to 6 months in a large integrated health care system in the USA: a retrospective cohort study. Lancet 2021; 398: 1407-414.

23. Monod M, Blenkinsop A, Xi X, et al. Age groups that sustain resurging COVID-19 epidemics in the United States. Science 2021 Feb 2:eabe8372. doi: 10.1126/science. abe8372.

24. Thomas SJ, Moreira ED Jr, Kitchin N, et al.; C4591001 Clinical Trial Group. Safety and efficacy of the BNT162b2 mRNA Covid-19 vaccine through 6 months. N Engl J Med 2021 Sep 15. doi: 10.1056/NEJMoa2110345.

25. Wiliamson EJ, Walker AJ, Bhaskaran K, et al. Factors associated with COVID-19-related death using OpenSAFELY. Nature 2020; 584: 430-6.

26. World Health Organization (WHO). Ethics and COVID-19: resource allocation and priority-setting (WHO/ RFH/20.2). https://www.who.int/ethics/publications/ ethics-covid-19-resource-allocation.pdf (who.int). Accessed January 20, 2021.

27. Debrabant K, Grønbæk L, Kronborg C. The cost-effectiveness of a COVID-19 vaccine in a Danish Context. Discussion Papers on Business and Economics, University of Southern Denmark, 2/2021. https://ssrn. com/abstract=3773381 or http://dx.doi.org/10.2139/ ssrn.3773381. Accessed February 24, 2021.

28. Padula WV, Malaviya S, Reid NM, et al. Economic value of treatment and vaccine to address the COVID-19 pandemic: a U.S. cost-effectiveness and budget impact analysis (4/22/2020). https://ssrn. com/abstract=3586694 or http://dx.doi.org/10.2139/ ssrn. 3586694 . 